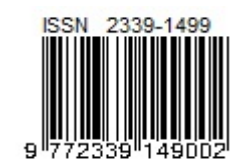

\title{
Perancangan Sistem Informasi Perawatan Mesin Pada PT XYZ
}

\author{
Berry Yuliandra ${ }^{1}$, Kushisa Atta Jaeba ${ }^{2}$ \\ 1) Jurusan Teknik Mesin Fakultas Teknik Universitas Andalas \\ Kampus Universitas Andalas Limau Manis Padang 25163 \\ Email: berry@ft.unand.ac.id \\ 2) Jurusan Teknik Industri Fakultas Teknik Universitas Andalas \\ Kampus Universitas Andalas Limau Manis Padang 25163
}

\begin{abstract}
Maintenance management is an important aspect that define success and sustainability of a manufacturing industry. The development of information technology give new possibilities to improve maintenance management performance. Data management with the help from information system will improve maintenance management effectiveness and efficiency. PT XYZ is an industry specialized in retreading tires service. Preliminary study on machinery maintenance process in PT XYZ showed that breakdown and maintenance data were not properly documented. This can generate high cost for the company because maintenance scheduling cannot optimally determined and the cost incurred by repair and maintenance activities, and also the cost of lost production time cannot determined directly. Therefore PT XYZ need information system to improve their maintenance management efficiency. Information system designed in accordance with company need based on system survey and interview. The design of information system developed using Object Oriented Analysis (OOA) and Object Oriented Design (OOD) approach. The designed information system can help maintenance management implementation and related data management. The availability of repair and maintenance data can help factory supervisor to make decision related to maintenance activities such as parts needed and maintenance cost.
\end{abstract}

Kata kunci: Perawatan mesin, sistem informasi, kinerja

\begin{abstract}
Abstrak
Manajemen perawatan mesin merupakan aspek penting yang menentukan keberhasilan dan keberlanjutan suatu industri manufaktur. Perkembangan teknologi informasi memberikan peluang baru bagi peningkatan kinerja manajemen perawatan. Pengelolaan data dengan bantuan sistem informasi akan meningkatkan efektivitas dan efisiensi aktivitas manajemen perawatan mesin. PT XYZ merupakan perusahaan yang bergerak dalam jasa vulkanisir ban. Kajian awal terhadap proses perawatan mesin pada PT XYZ menunjukkan bahwa data kerusakan dan perawatan mesin belum didokumentasikan dengan baik. Kondisi ini berpotensi untuk merugikan perusahaan karena jadwal perawatan mesin tidak bisa ditentukan secara optimal dan biaya yang ditimbulkan oleh aktivitas perbaikan, perawatan dan terhentinya produksi tidak bisa ditentukan secara langsung. Oleh karena itu PT XYZ membutuhkan sistem informasi yang mampu meningkatkan efisiensi manajemen perawatan mesinnya. Sistem informasi dirancang sesuai kebutuhan perusahaan berdasarkan hasil survei sistem dan wawancara. Perancangan sistem informasi dilakukan menggunakan pendekatan Object Oriented Analysis (OOA) dan Object Oriented Design (OOD). Hasil perancangan sistem informasi dapat mempermudah pelaksanaan manajemen perawatan dan pengelolaan data-data terkait. Ketersedian rekapitulasi data kerusakan dan perawatan mesin membantu kepala pabrik untuk mengambil keputusan-keputusan yang berhubungan dengan aktivitas perawatan seperti jenis komponen yang diperlukan dan biaya perbaikan mesin.
\end{abstract}

Kata kunci: Perawatan mesin, sistem informasi, kinerja

\section{Pendahuluan}

Manajemen perawatan mesin merupakan salah satu aspek manufaktur yang memainkan peran penting dalam kesuksesan dan keberlanjutan sebuah perusahaan (Parida dan Kumar (2006), khususnya dalam meningkatkan produktivitas dan kualitas produksi (Labib, 2008). Argumen ini didukung oleh hasil penelitian Onohaebi dan Lawal (2010) yang menunjukkan bahwa buruknya aktivitas perawatan mesin menjadi penyebab rendahnya output produksi. Penelitian yang dilakukan Samat et al. (2011) juga menunjukkan bahwa efektivitas kegiatan perawatan mesin dapat memberikan dampak 
positif terhadap operasi dan keuntungan organisasional.

Paradigma yang mendasari manajemen perawatan mesin itu sendiri telah mengalami perubahan yang signifikan dari masa awal kemunculannya. Pada awal 1900-an manajemen perawatan dianggap sebagai "necessary evir". Manajemen perawatan pada era tersebut dianggap sebagai suatu hal yang tidak memberikan keuntungan tetapi harus dilaksanakan untuk memastikan agar kegiatan produksi tetap berjalan lancar. Paradigma tersebut bergeser pada era 1995-2000 dimana manajemen perawatan dianggap sebagai salah satu fungsi pendukung utama manufaktur. Pada era modern saat ini, paradigma mengenai manajemen perawatan telah berkembang lebih jauh lagi dengan menganggapnya sebagai bagian integral proses bisnis perusahaan (Parida dan Kumar, 2006).

Menurut paradigma modern, perawatan mesin tidak hanya sekedar tindakan korektif, tetapi merupakan tindakan administratif terencana untuk mencapai keseimbangan antara kemampuan organisasional dengan kebutuhan stakeholders (Kennedy, 2009). Oleh karena tindakan perawatan mesin sudah dianggap sebagai tindakan administratif yang terencana, maka pengendalian kinerja perlu diterapkan untuk menjaga kualitas dari hasil pelaksanaannya. Pengendalian kinerja perawatan mesin tersebut tidak hanya diperlukan pada lantai produksi saja, tetapi juga pada seluruh tingkatan manajemen perusahaan (Yuliandra, 2011).

Seiring dengan kondisi tersebut, perkembangan Teknologi Informasi dan Komunikasi (TIK) yang dimulai pada tahun 1990an dan terus berlanjut hingga sekarang ikut menjadi salah satu aspek pendukung penting yang menentukan efektivitas dan efisiensi manajemen perusahaan. Informasi yang jelas dan akurat bermanfaat dalam proses pengelolaan, perbaikan dan optimalisasi kinerja perusahaan, termasuk perusahaan yang bergerak dibidang manufaktur. Arti penting pengelolaan informasi merupakan alasan utama yang mendorong berbagai perusahaan untuk mengembangkan sistem informasinya sendiri.

Manajemen perawatan termasuk salah satu aspek manufaktur yang dapat mengambil manfaat dari perkembangan teknologi informasi tersebut. Implementasi manajemen perawatan memerlukan pengelolaan berbagai jenis data seperti kerusakan mesin, perbaikan mesin dan sebagainya. Pengelolaan data dengan bantuan sistem informasi akan membantu meningkatkan efektivitas dan efisiensi manajemen perawatan mesin.

PT XYZ merupakan perusahaan yang bergerak dalam jasa vulkanisir ban. Pelaksanaan manajemen perawatan PT XYZ belum menerapkan sistem informasi yang mampu menyimpan dan mengelola data secara cepat. Kondisi ini berpotensi untuk merugikan perusahaan karena jadwal perawatan mesin tidak bisa ditentukan secara optimal dan biaya yang ditimbulkan oleh aktivitas perbaikan, perawatan dan terhentinya produksi tidak bisa ditentukan secara langsung. Oleh karena itu PT XYZ membutuhkan sistem informasi yang mampu untuk meningkatkan efisiensi manajemen perawatan mesinnya.

Penelitian ini fokus terhadap perancangan sistem informasi perawatan mesin pada PT $X Y Z$. Sistem informasi tersebut diharapkan dapat meningkatkan efektivitas dan efisiensi manajemen perawatan di PT XYZ.

\section{Tinjauan Pustaka}

Tinjauan pustaka lebih ditekankan pada pembahasan mengenai state of the art dari perkembangan konsep manajemen perawatan dan sistem informasi.

\section{Manajemen Perawatan Mesin}

Peranan manajemen perawatan dalam dunia industri terus meningkat disebabkan semakin mahalnya biaya pembelian teknologi baru (Bartz et al., 2014). Aktivitas Perawatan dilakukan untuk memastikan agar proses manufaktur dapat beroperasi secara efektif dan efisien dengan jalan memperbaiki, mengganti, menyesuaikan dan memodifikasi semua mesin dan peralatan sesuai dengan kebutuhan produksi (Arts et al., 1998; Parida dan Kumar, 2006). Proses manufaktur yang efektif dan efisien pada akhirnya akan berdampak terhadap tingkat produktivitas, kualitas, dan kepuasan pelanggan sesuai dengan yang diharapkan. Oleh karena itu bisa dikatakan bahwa manajemen perawatan mesin yang dilaksanakan dengan baik akan 
membantu perusahaan dalam mencapai ketiga tujuan tersebut (Arniaz et al., 2006).

Perawatan dapat didefinisikan sebagai fungsi bisnis pada level operasional yang bertanggung jawab terhadap pemantauan, perencanaan operasi perbaikan, serta pelaksanaan berbagai aktivitas lainnya yang diperlukan untuk mengembalikan kondisi optimal fasilitas dan peralatan (Organization for Economic Cooperation and Development, 1963). Secara sederhana dapat dikatakan bahwa perawatan adalah segala aktivitas yang dilakukan untuk menjaga agar mesin dan peralatan dapat tetap bekerja. Meskipun definisi tersebut tidak berubah dan tetap relevan hingga masa sekarang ini, cara pandang terhadap konsep perawatan dan ruang lingkupnya terus mengalami perrkembangan seiring berjalannya waktu. Pada awal perkembangannya aktivitas perawatan hanya dianggap sebagai "necessary evil", yaitu pengeluaran yang diperlukan untuk menjaga agar fasilitas dan peralatan produksi dapat tetap beroperasi dengan baik. Era 1940-1950an menandai perkembangan signifikan pertama dari konsep manajemen perawatan melalui munculnya konsep corrective maintenance.

Corrective maintenance merupakan strategi manajemen perawatan mesin yang fokus terhadap usaha pengembalian kapabilitas peralatan (Sachdeva et al., 2008). Karakteristik tersebut menyebabkan corrective maintenance juga sering disebut sebagai reactive maintenance. Sifatnya yang reaktif menyebabkan corrective maintenance hanya mampu memenuhi kebutuhan bisnis secara parsial. Akan tetapi, risiko terbesar dari corrective maintenance adalah tingginya downtime dan penurunan level produksi yang tidak diharapkan (Bartz et al., 2014). Menurut Karim et al. (2009), risiko tersebut menjadikan perlunya pengembangan metode perencanaan perawatan lain agar bisa mengiringi kompleksitas evolusi teknologi peralatan. Kondisi tersebut mendorong munculnya berbagai konsep manajemen perawatan pada era setelahnya. Sekarang ini corrective maintenance sebaiknya hanya digunakan ketika pendekatan lain justru membutuhkan biaya yang lebih besar.

Generasi kedua konsep manajemen perawatan dimulai pada era 1950-1980an, yang ditandai dengan meningkatnya popularitas preventive maintenance. Secara garis besar, pendekatan preventive maintenance dapat dibagi ke dalam dua kelompok: time-based maintenance dan condition-based maintenance (Meselhy et al., 2009). Time-based maintenance merupakan aktivitas perawatan yang dilakukan secara regular sesuai dengan jadwal yang telah ditetapkan sebelumnya. Karakteristik ini menyebabkan time-based maintenance juga sering disebut dengan istilah periodic maintenance. Berbeda dengan time-based maintenance, condition-based Maintenance dilakukan berdasarkan pemantauan kondisi peralatan. Tujuannya adalah untuk memprediksi sisa hidup peralatan, menghindari tindakan perawatan yang tidak perlu, serta meminimasi biaya siklus hidup peralatan sambil meningkatkan reliabilitasnya (Mobley, 1989). Pemantauan dapat dilakukan secara langsung maupun tidak langsung (Christer dan Wang, 1995; Raheja et al., 2006), serta secara kontinu maupun periodik (Wang, 2000).

Generasi ketiga dimulai pada era 1980 hingga 2000an. Pada masa ini manajemen perawatan lebih terfokus pada pencegahan kerusakan peralatan, serta peningkatan ketersediaan (availability) dan reliabilitas dari peralatan tersebut pada saat dioperasikan. Beberapa strategi manajemen perawatan yang muncul pada era ini antara lain: Total Productive Maintenance (TPM), reliabilitycentered maintenance, dan predictive maintenance (Khalil et al., 2009).

Generasi keempat merupakan era proactive maintenance yang dimulai dari tahun 2000an. Pendekatan tersebut menyesuaikan strategi perawatan dengan tujuan organisasional, atau dengan kata lain perawatan dianggap sebagai langkah strategis yang diperlukan untuk menjaga agar peralatan dapat tetap berproduksi secara berkelanjutan. Aktivitas perawatan yang memadai untuk sistem manajemen modern tidak lagi terbatas hanya pada perbaikan, kualitas dan produktivitas saja, tetapi juga harus mampu mempengaruhi output organisasional (Bartz et al., 2014). Penggunaan pendekatan berbasis data menjadi penting bagi manajemen perawatan untuk bisa mencapai tujuan organisasional tersebut (Verron et al., 2010). Oleh karena itu penerapan sistem informasi menjadi penting dalam manajemen perawatan 
pada masa sekarang ini. Tretten dan Karim (2014) mengemukakan bahwa penggunaan teknologi informasi dapat membantu perencanaan dan eksekusi perawatan peralatan pada berbagai industri kertas, tambang, dan aerospace.

\section{Sistem Informasi}

Sistem informasi dapat didefinisikan sebagai sistem yang menghubungkan kebutuhan pengolahan transaksi harian, dukungan operasi, aktivitas manajemen dan strategi dalam suatu organisasi untuk menyediakan berbagai laporan yang dibutuhkan, baik bagi keperluan internal maupun pihak luar tertentu (Leitch dan Davis, 1992). Sebuah sistem informasi merupakan hasil rancangan manusia, dan terdapat Beberapa metodologi yang dapat digunakan untuk mengembangkan sistem informasi. Metodologi-metodologi tersebut antara lain:

1. Metodologi Berorientasi Output

Fokus utama dari metodologi ini adalah keluaran atau output yang ingin dihasilkan oleh sistem.

2. Metodologi Berorientasi Proses

Metodologi ini juga sering disebut metodologi struktur analisis dan desain yang dibutuhkan dalam pengembangan sistem. Fokus utama metodologi ini adalah proses dari sistem yang dikaji.

3. Metodologi Berorientasi Data

Merupakan metodologi pemodelan informasi dengan menggunakan Entity Relationship Diagram (ERD).

4. Metodologi Berorientasi Objek

Metodologi ini fokus terhadap perilaku dan hubungan antar objek yang terdapat di dalam sistem. Metodologi ini menggunakan Object Oriented Analysis (OOA) serta Object Oriented Design (OOD).

Object Oriented Analysis (OOA) pertama kali digunakan pada tahun 1988 oleh Mellor, Jacobson, Coad-Yourdon dan Rumbaugh. Pada dasarnya OOA adalah metode analisis sistem yang memisahkan antara data dan proses. Seluruh data bersifat spesifik dan proses merupakan segala aktivitas pembuatan, pembacaan, memperbarui atau penghapusan data.

Objek bisa dipandang sebagai sebuah item informasi atau representasi entitas dunia nyata. OOA merepresentasikan permasalahan dunia nyata melalui serangkaian objek. Cara ini memiliki beberapa kelebihan, khususnya dalam pengembangan software:

1. Maintainability, yaitu memberikan kemudahan dalam mengakomodasi perubahan-perubahan.

2. Mengurangi kompleksitas perancangan sistem.

3. Reusability, yaitu bisa digunakan kembali dalam perancangan selanjutnya. Kekurangan dari software yang telah dihasilkan dapat diperbaiki kembali tanpa memerlukan perubahan signifikan pada model dasarnya. Hal ini dapat menghemat waktu dan biaya dalam usaha pengembangan.

Berbagai kelebihan tersebut menjadikan pendekatan OAA sering digunakan pada masa sekarang. Kemampuannya untuk dapat digunakan kembali mendukung usaha pengembangan software, sehingga versi baru software dapat diciptakan dalam waktu singkat. Proses OOA memanfaatkan notasi Unified Modelling Language (UML) untuk menggambarkan model yang dirancang.

Unified Modelling Language (UML) pada dasarnya merupakan serangkaian notasi serta aturan yang digunakan sebagai standar umum untuk mendeskripsikan model dalam bentuk hubungan antar objek (Blaha dan Rumbaugh, 2005). Dalam terminologi sistem informasi, UML dianggap sebagai "bahasa" yang digunakan untuk visualisasi, merancang dan mendokumentasikan sistem software. Fungsi utama UML adalah membantu perancangan sistem informasi berdasarkan hubungan antar objek yang terlibat. Beberapa jenis diagram UML yang umum digunakan antara lain:

1. Business Process Diagram, merupakan diagram yang digunakan untuk memodelkan kegiatan-kegiatan yang terjadi di dalam sistem. Model tersebut berupa alur kegiatan dan aliran informasi (berupa data) serta menampilkan input, proses, output dan sumber daya yang tersedia.

2. Use Case Diagram, merupakan diagram yang menggambarkan sekumpulan aktor dan interaksinya terhadap sistem. Diagram ini berfungsi untuk merepresentasikan kebutuhan pengguna terhadap sebuah sistem serta 
memodelkan fungsionalitas yang diharapkan dari sistem tersebut. Notasi use case disimbolkan dengan objek berbentuk oval.

Secara garis besar, use case terdiri atas dua elemen utama. Kedua elemen tersebut adalah:

- Aktor, merupakan seseorang atau objek diluar sistem yang melakukan interaksi dengan sistem untuk melaksanakan suatu pekerjaan tertentu. Notasi UML untuk aktor adalah "stickman" (Blaha dan Rumbaugh, 2005)

- Relationship, merupakan hubungan antara dua atau lebih aktor dengan use case. Notasi UML untuk relationship adalah garis lurus.

3. Activity Diagram, menggambarkan logika prosedural, proses bisnis dan alur kerja. Jenis diagram ini memiliki kemiripan dengan flowchart. Perbedaan diantara kedua diagram tersebut adalah activity diagram digambar menggunakan notasi UML, bukan dengan simbol baku flowchart (Christianti dan Wijaya, 2011). Penggambaran dalam activity diagram hanya berupa aturan rangkaian dasar yang harus diikuti. Implementasi dari proses yang digambarkan tersebut bisa saja dilakukan secara paralel.

4. Class Diagram, merupakan diagram yang mendeskripsikan objek-objek yang ada di dalam suatu sistem beserta hubungan diantara berbagai objek tersebut. Setiap kelas memiliki nama, atribut dan operasi. Relasi antar kelas menggambarkan hubungan keterkaitan antar kelas. Selama proses analisa class diagram berfungsi untuk menjelaskan aturan-aturan serta tanggung jawab masing-masing entitas yang menentukan perilaku sistem. Pada tahap perancangan class diagram berperan dalam menangkap struktur dari semua kelas yang membentuk arsitektur sistem.

5. Entity Relationship Diagram (ERD), merupakan diagram yang digunakan untuk mendeskripsikan berbagai data/ objek sebagai entitas serta menggambarkan hubungan diantara entitas tersebut berdasarkan kondisi nyata menggunakan notasi-notasi tertentu. Setiap pemrosesan data dapat digambarkan secara transaksional dengan jelas menggunakan ERD (Edi dan Betshani, 2009). Langkah-langkah yang dapat digunakan untuk menggambarkan ERD antara lain (Prihatini, 2012):
a. Identifikasi setiap entitas yang terlibat di dalam sistem.
b. Identifikasi atribut dari setiap entitas.
c. Tentukan primary key dari setiap entitas.
d. Identifikasi hubungan antar entitas.
e. Gambarkan model entitas.

\section{Metodologi}

Metodologi yang digunakan meliputi tahaptahap sebagai berikut:

1. Survei Sistem

Tahap awal ini bertujuan untuk mengetahui mekanisme aktual dari sistem perawatan mesin pada PT XYZ. Survei dilakukan melalui wawancara dan diskusi dengan pihak terkait. Informasi yang dikumpulkan adalah jenis komponen yang terlibat dalam sistem, proses perawatan mesin serta data lainnya yang terkait.

2. Studi Literatur

Studi literatur dilakukan untuk mempelajari metodologi pengembangan sistem informasi yang sesuai dengan kebutuhan.

3. Pengumpulan Data

Pengumpulan data dilakukan terhadap serangkaian data yang dibutuhkan bagi pengembangan sistem. Jenis data yang dibutuhkan antara lain: struktur organisasi, mesin yang digunakan, rekapitulasi data kerusakan mesin serta data-data lainnya yang diperlukan.

4. Pemodelan Sistem Informasi

Secara garis besar pemodelan sistem informasi dilakukan melalui dua tahapan berikut:

a. Analisis Sistem

Analisis sistem dilakukan untuk mengidentifikasi dan mempelajari kekurangan yang ada pada sistem. Gambaran serta tujuan dari sistem yang akan dirancang dapat dipahami dengan jelas melalui langkah ini.

b. Pemodelan Sistem

$\begin{array}{llr}\text { Pemodelan } & \text { sistem dilakukan } \\ \text { berdasarkan hasil analisis } & \text { sistem. } \\ \text { Metodologi } & \text { berorientasi objek }\end{array}$


digunakan untuk merancang sistem informasi karena berbagai kelebihan dari metodologi tersebut yang telah dibahas pada bagian sebelumnya.

Penggambaran model dilakukan menggunakan diagram UML. Akan tetapi untuk efisiensi proses pemodelan, hanya Business Process Diagram, Use Case Diagram, Activity Diagram dan Class Diagram saja yang digunakan. Entity Relationship Diagram dirancang berdasarkan model Class Diagram.

Urutan langkah perancangan sistem informasi yang digunakan adalah sebagai berikut:

Tahap 1 Perancangan process business diagram

Tahap ini bertujuan untuk menggambarkan hubungan antar aktivitas serta aliran informasi yang terjadi di dalam sistem.

Tahap 2 Perancangan use case diagram

Tujuan tahapan ini adalah untuk menggambarkan pola interaksi user dengan sistem.

Tahap 3 Perancangan activity diagram

Tahap ini dilakukan untuk menggambarkan proses urutan kegiatan yang harus dilalui oleh user dalam menggunakan sistem.

Tahap 4 Perancangan class diagram Tujuan tahapan ini adalah menggambarkan struktur, deskripsi dan hubungan dari semua objek yang terlibat di dalam sistem.

Tahap 5 Perancangan entity
Tahap ini bertujuan untuk menggambarkan hubungan dari berbagai entitas yang terdapat dalam suatu kelas dengan entitas pada kelas lainnya.

5. Perancangan Sistem Informasi

Perancangan sistem informasi dilakukan berdasarkan hasil pemodelan sistem. Tahap perancangan yang dilakukan dalam penelitian ini menggunakan langkah-langkah berikut:

a. Analisis terhadap aliran data dan informasi.

b. Perancangan database sistem.

c. Perancangan user interface.

6. Perbaikan

Perbaikan terhadap hasil rancangan dilakukan hanya jika memang diperlukan.

\section{Hasil dan Pembahasan}

\section{Pemodelan Sistem Informasi}

Proses perancangan sistem informasi difokuskan pada aktivitas manajemen perawatan PT XYZ. Perancangan diarahkan untuk memperlancar aliran informasi.

Proses bisnis menggambarkan seluruh kegiatan dan aliran informasi yang terjadi di dalam sistem. Model proses bisnis dikembangkan berdasarkan input, proses, sumber daya dan output yang ada dalam sistem. Perancangan sistem informasi difokuskan untuk dua proses aliran informasi pada manajemen perawatan PT XYZ, yaitu pencatatan dan pelaporan kerusakan mesin.

Business Process Diagram untuk pencatatan kerusakan mesin dapat dilihat pada Gambar 8, sementara untuk laporan kerusakan ditunjukkan oleh Gambar 9.

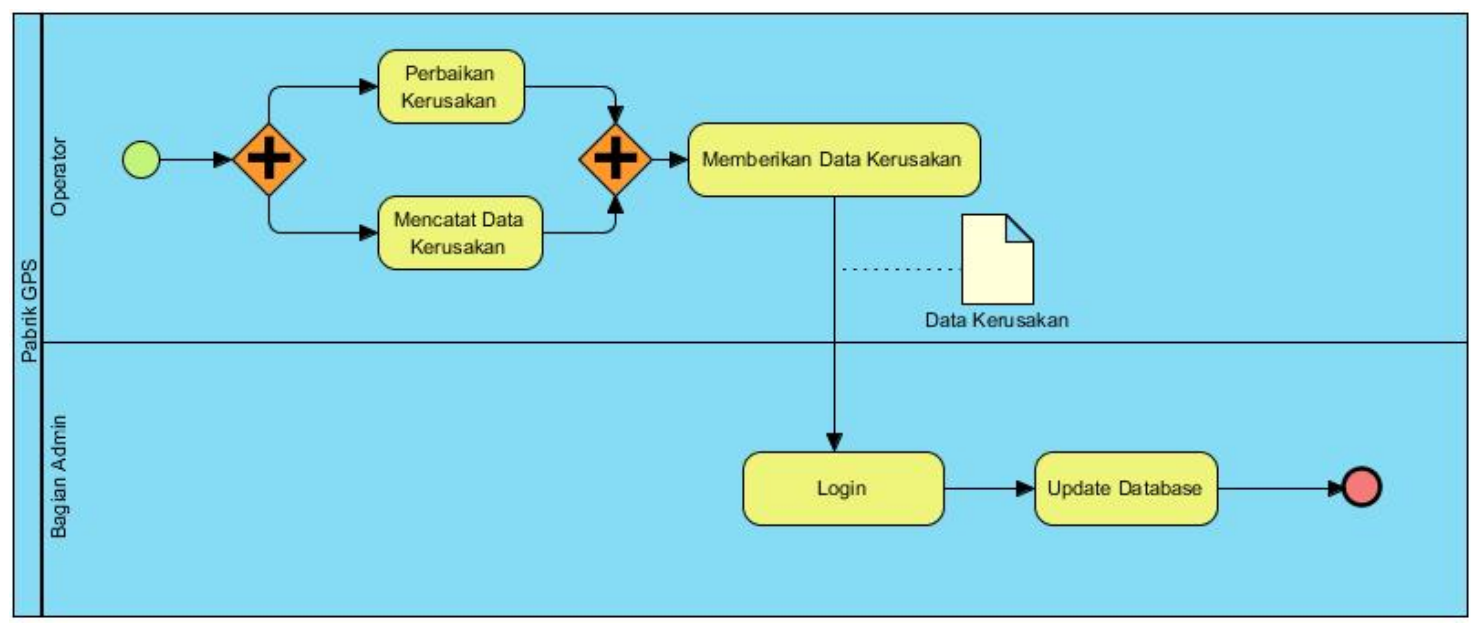


Gambar 8. Business Process Diagram Pencatatan Kerusakan Mesin

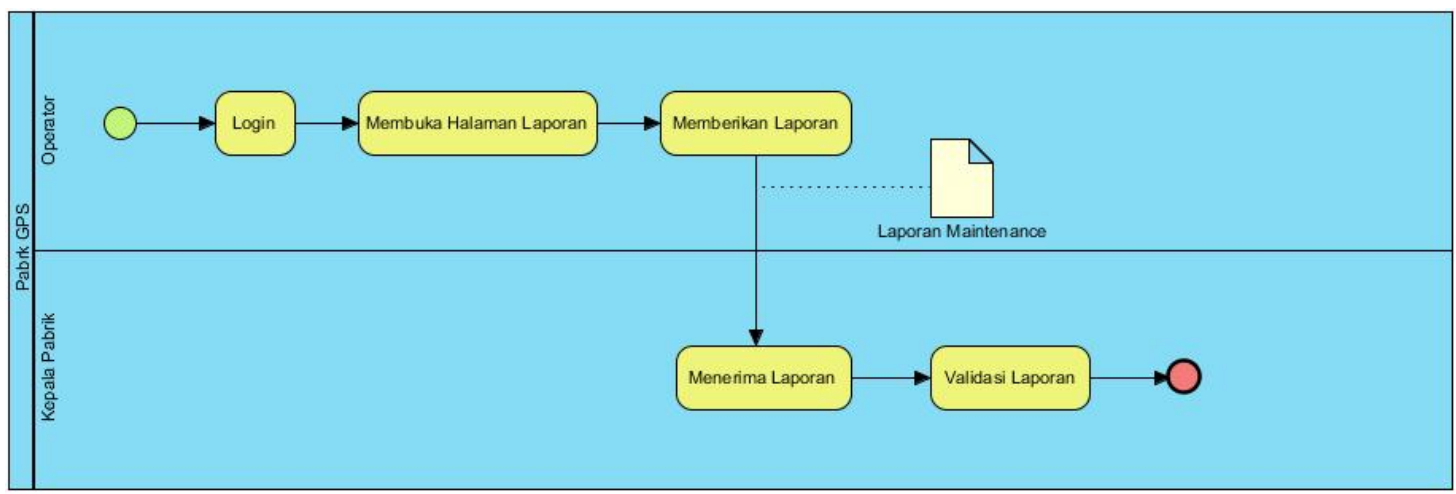

Gambar 9. Business Process Diagram Pelaporan Kerusakan Mesin

Use case diagram digunakan untuk menggambarkan interaksi antara user dengan sistem yang dirancang. Perancangan mendefinisikan tiga user yang dapat menggunakan sistem informasi manajemen perawatan, yaitu: Operator, Admin dan Kepala Pabrik. Gambar 10 memperlihatkan hasil perancangan use case diagram untuk aktivitas manajemen perawatan PT XYZ.

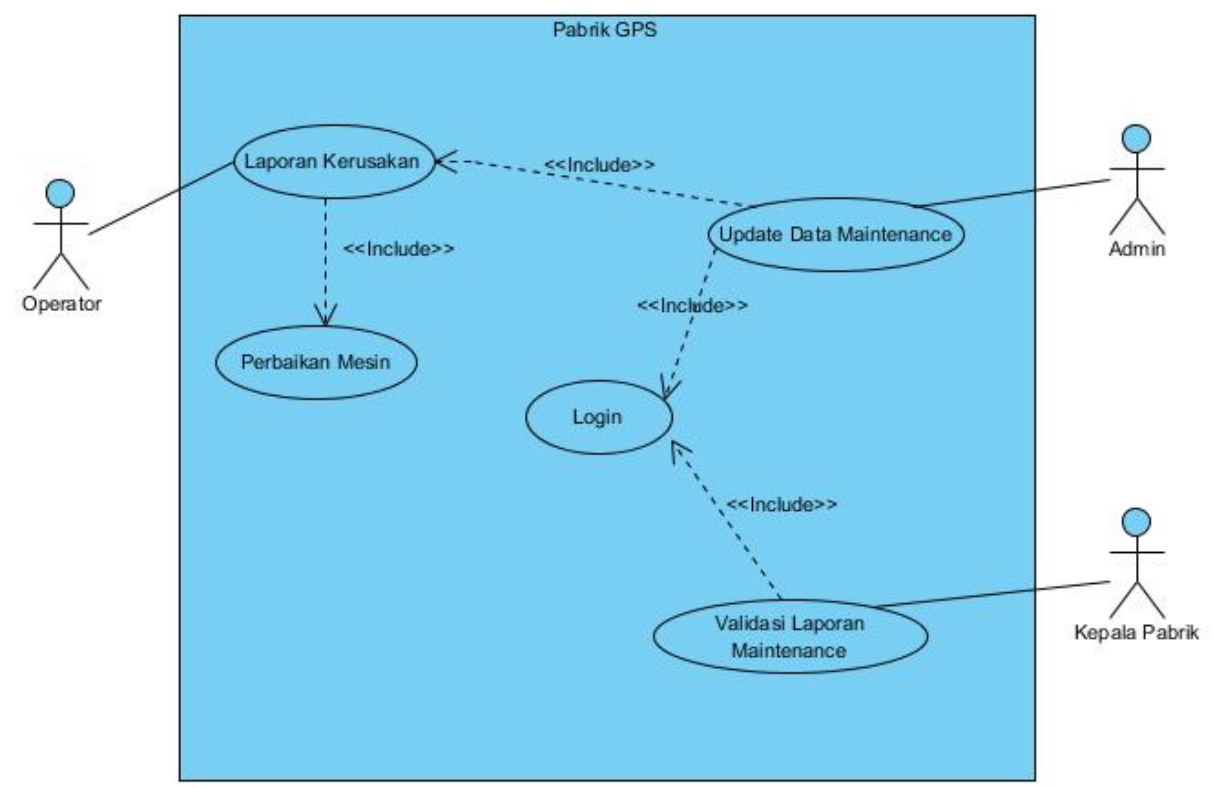

Gambar 10. Use Case Diagram Manajemen Perawatan PT XYZ

Activity diagram digunakan untuk menggambarkan aliran atau urutan kegiatan yang dilakukan oleh user yang ada di dalam sistem. Gambar 11 memperlihatkan activity diagram usulan untuk aktivitas perawatan. Sementara itu, untuk kegiatan validasi laporan perawatan dapat dilihat pada Gambar 12. 


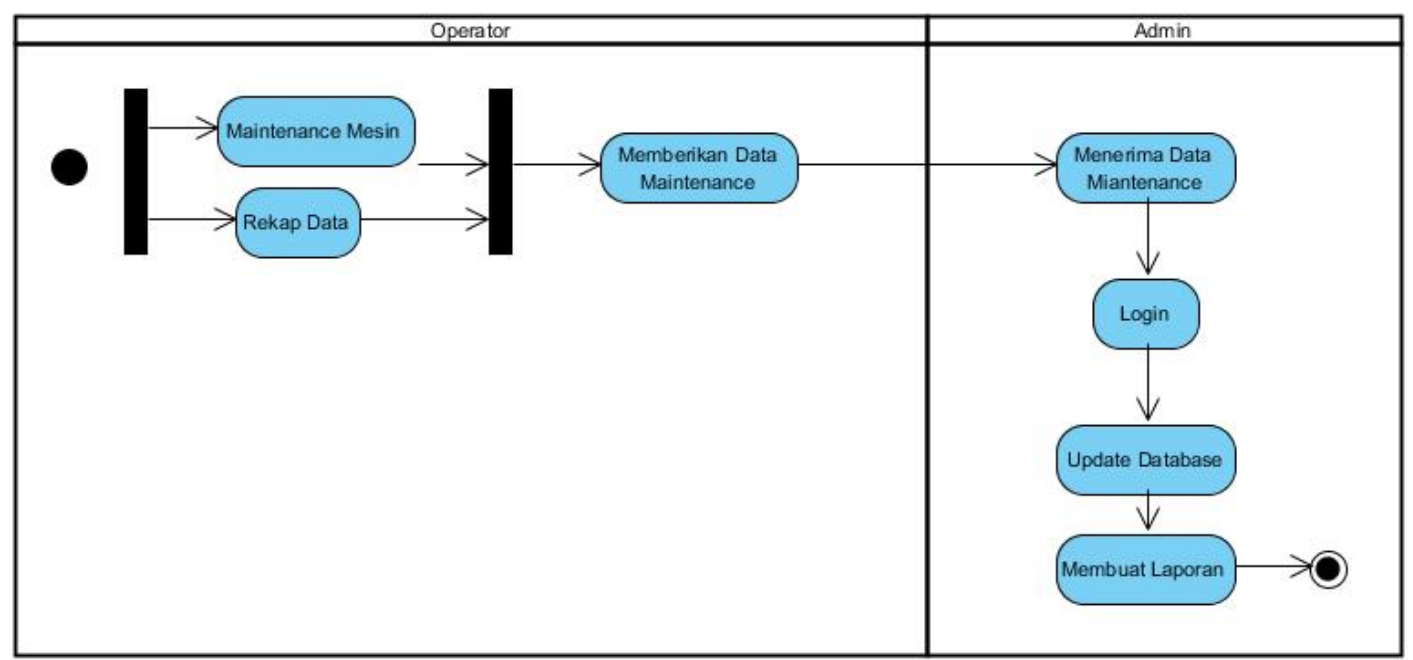

Gambar 11. Activity Diagram Aktivitas Perawatan

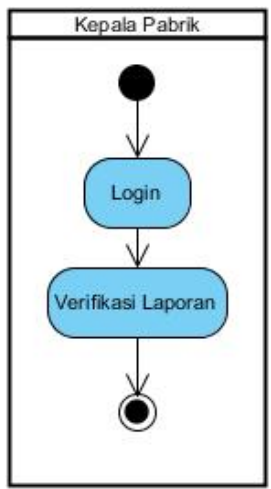

Class diagram menggambarkan struktur dan deskripsi class, package dan objek. Selain deskripsi, class diagram juga memperlihatkan hubungan diantara hal-hal tersebut seperti containment, inheritance, asosiasi dan sebagainya. Gambar 13 memperlihatkan class diagram untuk sistem informasi perawatan mesin PT XYZ.

Gambar 12. Activity Diagram Validasi Laporan Perawatan

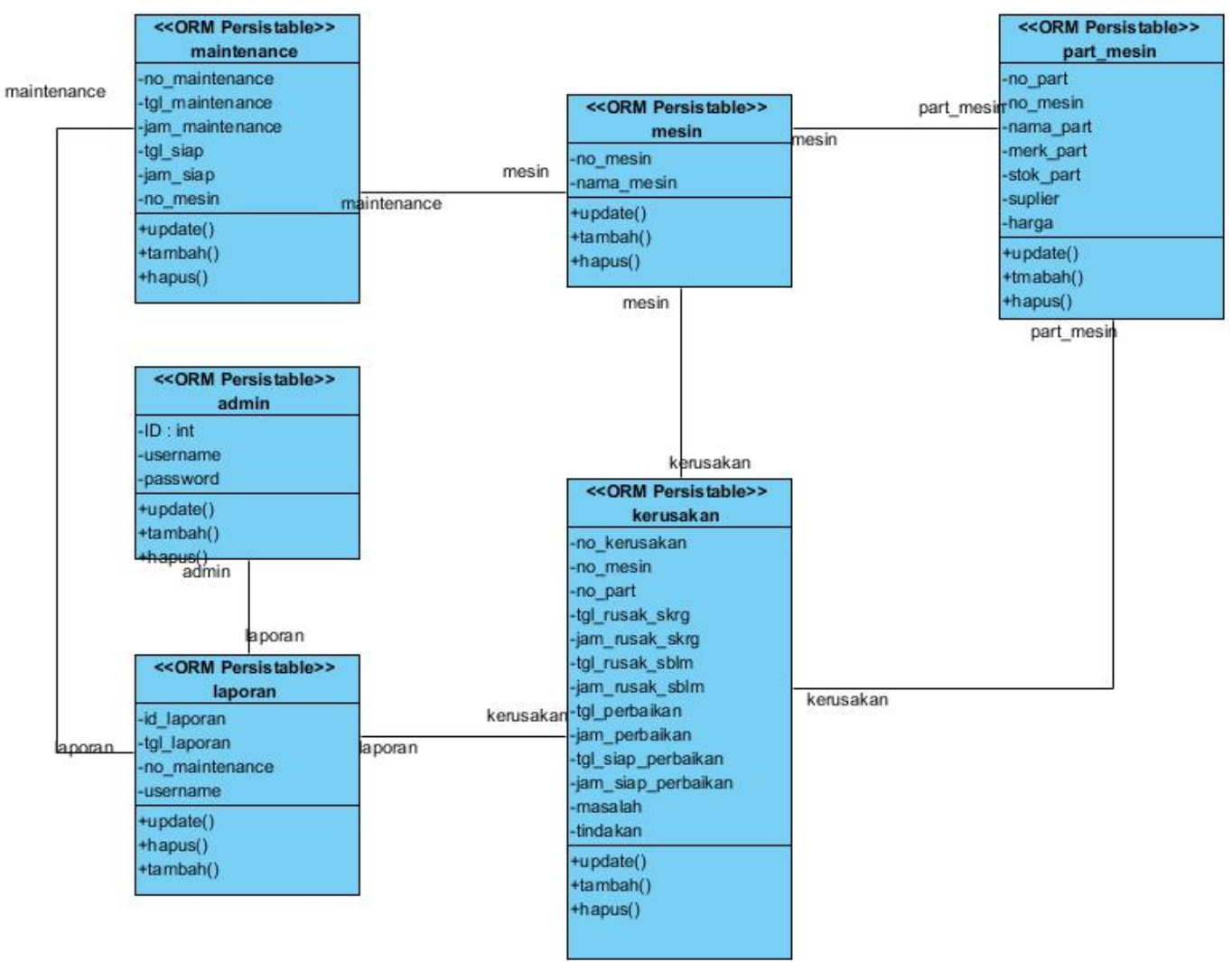

Gambar 13. Class Diagram Sistem Informasi Perawatan Mesin PT XYZ 
Entity Relationship Diagram (ERD) menggambarkan relasi antara masing-masing entitas dalam sebuah kelas. Pembuatan ERD didasarkan pada class diagram. Gambar 14 menunjukkan ERD untuk sistem informasi perawatan mesin pada $\mathrm{PT} X Y \mathrm{X}$.

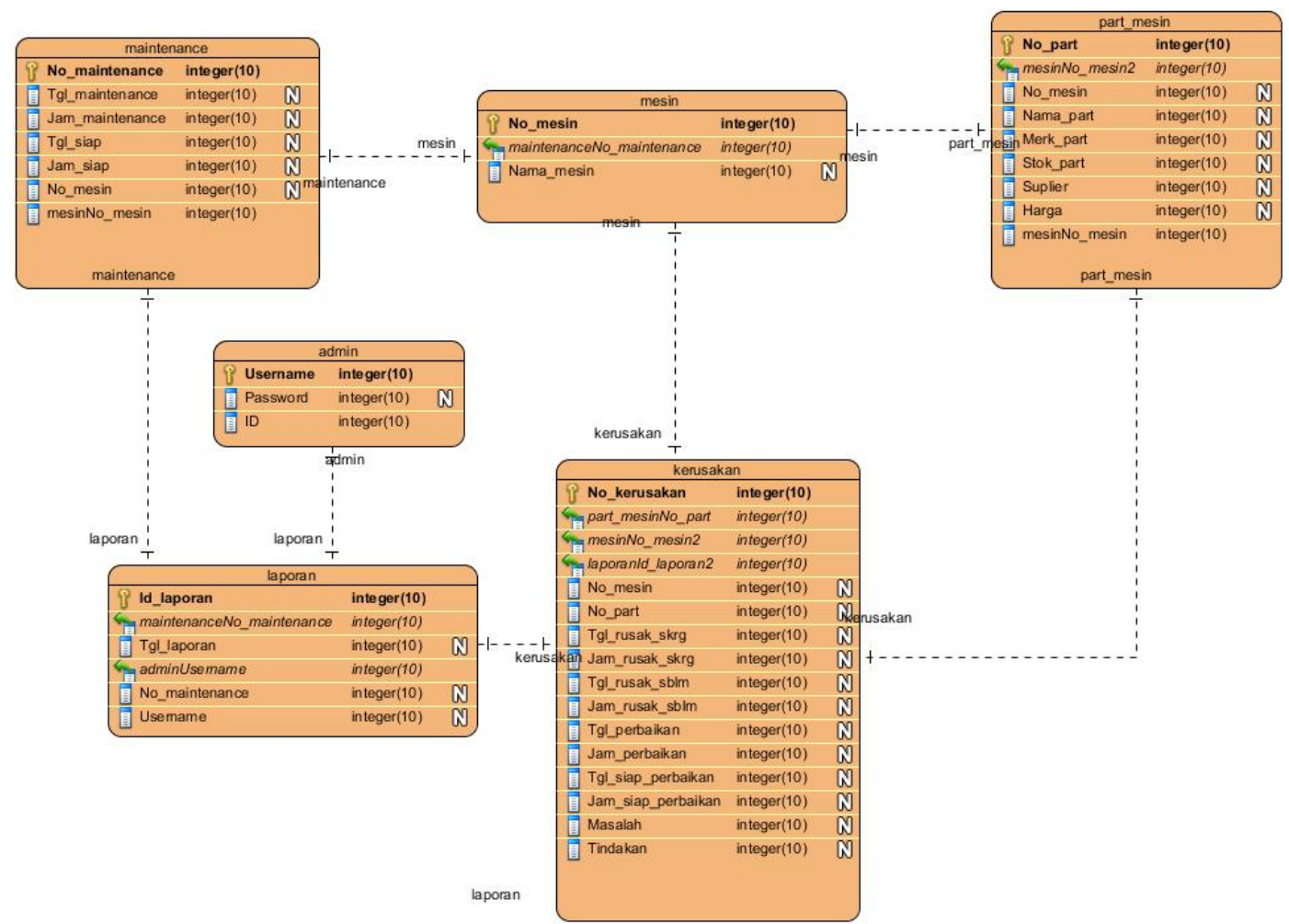

Gambar 14. Entity Retionship Diagram Sistem Informasi Perawatan Mesin PT XYZ

\section{Perancangan Sistem Informasi}

Perancangan sistem informasi perawatan mesin pada PT XYZ dilakukan untuk mempermudah proses penyimpanan dan pemanfaatan data kerusakan mesin. Melalui hal tersebut Supervisor Pabrik dapat mengetahui kondisi aktual mesin, data historis mesin serta biaya perawatan mesin dengan lebih cepat dan akurat. Sebelumnya pencatatan dan penyimpanan data mesin dilakukan secara manual, bahkan terkadang tidak dilaksanakan sama sekali.

Aliran data bermula dari laporan kerusakan dari operator serta tindakan perbaikan yang diambil. Data tersebut dicatat dan diperbarui oleh Administrator Pabrik sebagai aktor utama sistem. Segala kegiatan yang dilakukan oleh operator akan disampaikan secara langsung kepada Kepala Pabrik dalam bentuk laporan. Kepala Pabrik dapat mengakses database sistem informasi perawatan mesin untuk melakukan validasi terhadap laporan tersebut.

Database dirancang untuk merapikan dan menstabilkan struktur data melalui pengembangan rancangan yang logis.
Pengembangan logika database akan membantu perancangan fisik dari database tersebut. Perancangan database yang logis perlu mempertimbangkan setiap elemen data yang terlibat dalam sistem, baik input maupun output. Pengubahan hubungan/ relasi menjadi file akan menghasilkan sebuah database fisik. Model database relasional yang baik adalah model database dengan relasi yang terstruktur.

Perancangan database pada penelitian ini dilakukan menggunakan database Microsoft Access. Tabel-tabel pada database dirancang sedemikian rupa sehingga setiap tabel yang dihasilkan telah ternormalisasi. Setiap tabel memiliki primary key dan foreign key. Perancangan tersebut bertujuan untuk menghilangkan duplikasi data akibat pemberian atribut field yang salah.

Perancangan User Interface (UI) disesuaikan dengan kebutuhan dari user. UI yang dirancang meliputi halaman utama, halaman data perbaikan/ perawatan dan laporan. Hasil perancangan UI dapat dilihat pada Gambar 15 dan Gambar 16. 


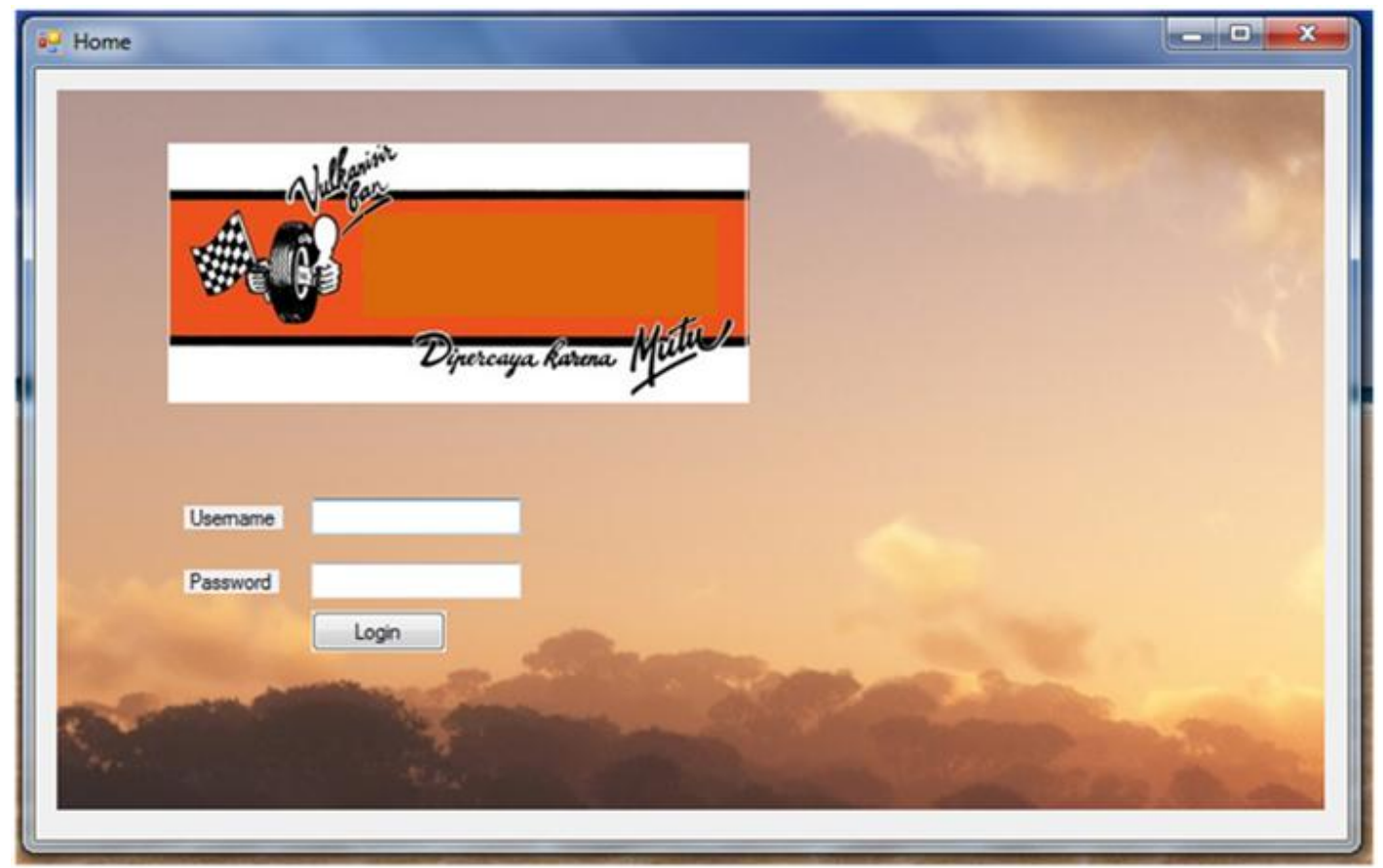

Gambar 15. User Interface Halaman Login

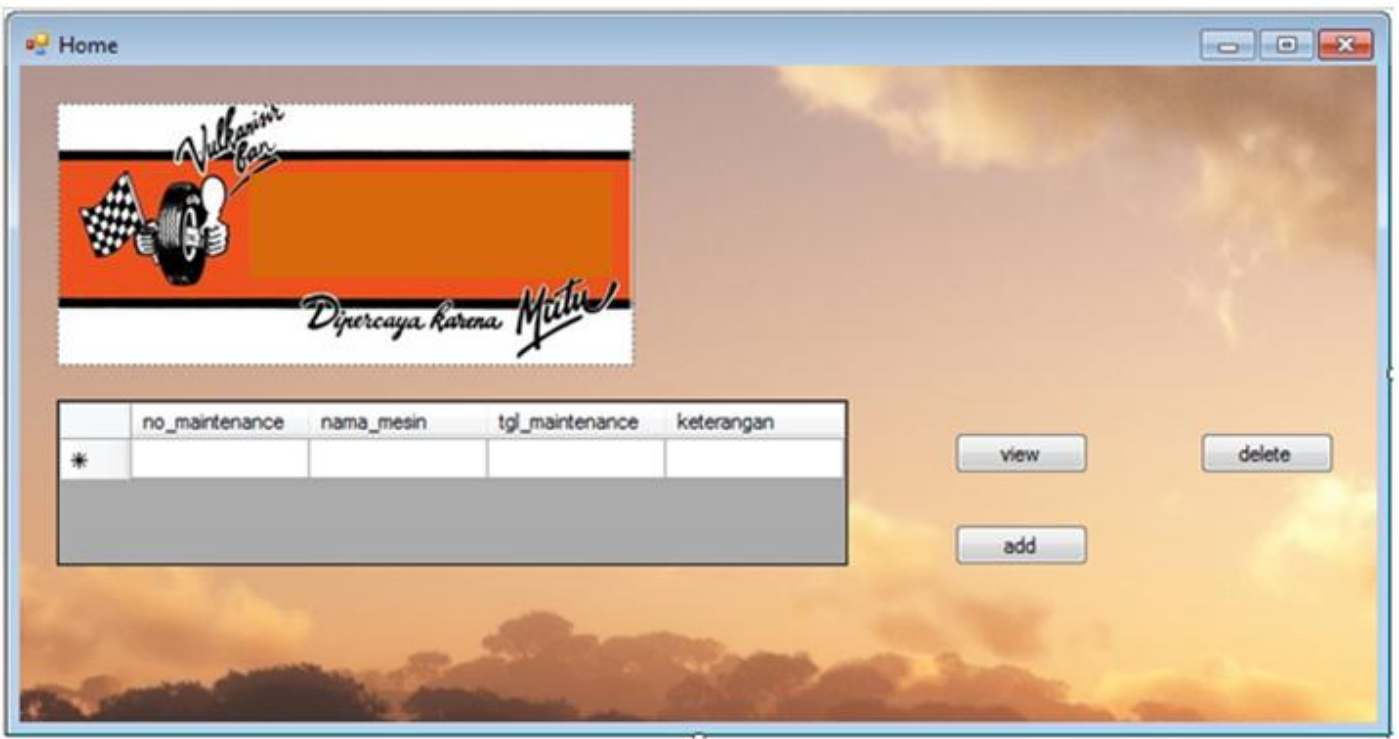

Gambar 16. User Interface Halaman Home

\section{Kesimpulan}

Hasil perancangan sistem informasi perawatan mesin dapat mempermudah pengelolaan dan pemanfaatan data perawatan mesin PT XYZ. Kondisi ini lebih baik dari kondisi sebelumnya dimana tidak terdapat rekapitulasi data kerusakan dan perawatan mesin yang jelas sehingga menyulitkan Kepala Pabrik dalam mengambil keputusan yang berkaitan dengan perawatan mesin. Beberapa keputusan yang dapat terbantu melalui implementasi sistem ini antara lain: penjadwalan aktivitas perawatan mesin, persediaan komponen yang diperlukan, serta biaya perawatan mesin.

Ruang lingkup perancangan sistem informasi pada penelitian selanjutnya sebaiknya lebih diperluas sehingga tidak hanya berfungsi untuk memperlancar aliran data aktivitas perbaikan/ perawatan saja, tetapi juga langsung dapat digunakan untuk menjadwalkan aktivitas perawatan mesin. Selain itu akan lebih baik jika sistem informasi yang telah dirancang ini dapat dikembangkan lebih lanjut menjadi Decision Support System (DSS). 


\section{Daftar Pustaka}

Arniaz, A., Emmanouilidis, C., lung, B. dan Jantunen, E. (2006). Mobile Maintenance Management. Journal of International Technology and Information Management, Vol. 15 (4), 11-22.

Arts, R.H.P.M, Knapp, G.M. and Man, L. Jr. (1998). Some Aspects of Measuring Maintenance Performance in the Process Industry. Journal of Quality in Maintenance Engineering, Vol. 4 (1), 611.

Bartz, T., Siluk, J.C.M. dan Bartz, A.P.B. (2014). Improvement of Industrial Performance with TPM Implementation. Journal of Quality in Maintenance Engineering, Vol. 20 (1), 2-19.

Blaha, M. dan Rumbaugh, J. (2005). Object Oriented Modelling and Design with UML 2nd Edition, Prentice Hall.

Christer, A.H. dan Wang, W. (1995). A Simple Condition Monitoring Model for A Direct Monitoring Process. European Journal of Operational Research, Vol. 82 (2), 258-269.

Christianti, M. dan Wijaya, L. (2011) Aplikasi Pembelian, "Penjualan Obat dan Laporan Keuangan Dengan Menerapkan Manajemen Persediaan", Jurnal Sistem Informasi, Vol. 6 (2).

Edi, D. dan Betshani, S. (2009). Analisis Data dengan Menggunakan ERD dan Model Konseptual Data Warehouse. Jurnal Informatika, Vol. 5 (1), 71-85.

Karim, R., Candell, O. dan Soderholm, P. (2009). E-Maintenance and Information Logistics: Aspects of Content Format. Journal of Quality in Maintenance Engineering, Vol. 15 (3), 308-324.

Kennedy, J. (2009). What Is Maintenance?, Journal The Asset, Vol. 3, Issue 1.

Khalil, J., Saad, S.M. dan Gindy, N. (2009). An Integrated Cost Optimization Maintenance Model for Industrial Equipment. Journal of Quality in Maintenance Engineering, Vol. 15 (1), 106-118.

Labib, A. W. (2008). Next Generation Maintenance Systems (NGMS): Emerging Educational and Training Needs to Support An Adaptive Approach to Maintenance Planning and Improve Decision Support. Proceedings of the 5th International Conference on Condition Monitoring and Machinery Failure Prevention Technologies, 15-18 Juli, Edinburgh, UK.

Leitch, R. A. dan Davis, K. R. (2005). Accounting Information Systems: Theory and Practice, Pennsylvania State University.

Meselhy, K.T., El Maraghy, W.H. dan El Maraghy, H.A. (2009). A Periodicity Metric for Assessing Maintenance Strategies. CIRP Journal of Manufacturing Science and Technology, Vol. 3 No. 2, pp. 135-141.

Mobley, R.K. (1989). An Introduction to Predictive Maintenance, New York: Butterworth-Heinemann.

Onohaebi, O. S. dan Lawal, Y. O. (2010). Poor Maintenance Culture: The Bane to Electrical Power Generation in Nigeria. Journal of Economics and Engineering, 28-33.

Organization for Economic Cooperation and Development (1963). Science and the Policies of Governments: The Implications of Science and Technology for National and International Affairs, Paris: OECD.

Parida, A. dan Kumar, U. (2006). Maintenance Performance Measurement (MPM): Issues and Challenges. Journal of Quality in Maintenance Engineering, Vol. 12 (3), 239-251.

Prihatini, P. M. (2012). Kajian Prosedur dan Model Sistem Penerimaan Mahasiswa Baru Online Politeknik Negeri Bali. Jurnal Logic, Vol. 12 (1), 38-45.

Raheja, D., Llinas, J., Nagi, R. dan Romanowski, C. (2006). Data Fusion/ Data Mining-Based Architecture for Condition-Based Maintenance. International Journal of Production Research, Vol. 44 (14), 2869-2887.

Samat, H. A., Kamaruddin, S. dan Azid, I. A. (2011). Maintenance Performance Measurement: A Review. Pertanika Journal Science and Technology, Vol. 19 (2), 199-211.

Sachdeva, A., Kumar, D. dan Kumar, P. (2008). Planning and Optimizing the Maintenance of Paper Production Systems In A Paper Plant. Computers \& Industrial Engineering, Vol. 55 (4), 817829. 
Tretten, P. dan Karim, R. (2014). Enhancing the Usability of Maintenance Data Management Systems. Journal of Quality in Maintenance Engineering, Vol. 20 (3), 290-303.

Verron, S., Li, J. dan Tiplica, T. (2010). Fault Detection and Isolation of Faults In A Multivariate Process With Bayesian Network. Journal of Process Control, Vol. 20 (8), 902-911.

Wang, W. (2000). A Model to Determine the Optimal Critical Level and the Monitoring Intervals in Condition Based Maintenance. International Journal of Production Research, Vol. 38 (6), 14251436.

Yuliandra, B. (2011). Hierarchical Maintenance Performance Measurement: A Literature Study, Proceeding of 2nd International Forum on Facilities and Asset Management (IFFAM), 21 November, Padang, Indonesia, 85-93. 